\title{
MOLECULAR CLONING AND EXPRESSION ANALYSIS OF HYPOXIA INDUCIBLE FACTOR $1 \alpha$ IN TONGUE SOLE, CYNOGLOSSUS SEMILAEVIS (ACTINOPTERYGII: PLEURONECTIFORMES: CYNOGLOSSIDAE), SUBJECTED TO ACUTE HYPOXIA
}

\author{
Zhi T. QI ${ }^{1,2,3^{*}}$, Zi S. WANG ${ }^{2}$, Qi H. ZHANG ${ }^{3}$, Wei H. ZHAO ${ }^{2}$, M. QIU ${ }^{2,3}$, \\ and Jian Q. PENG ${ }^{2}$ \\ ${ }^{1}$ Post-doctoral research station at Wuxi Fisheries College, Nanjing Agricultural University, \\ 214182, Wuxi, Jiangsu, China \\ ${ }^{2}$ Key Laboratory of Aquaculture and Ecology of Coastal pool of Jiangsu Province, \\ Department of Ocean Technology, Yancheng Institute of Technology, Yancheng, Jiangsu 224051, China \\ ${ }^{3}$ School of Chemical and Biological Engineering, Yancheng Institute of Technology, \\ Yancheng, Jiangsu 224051, China
}

\begin{abstract}
Qi Z.T., Wang Z.S., Zhang Q.H., Zhao W.H., Qiu M., Peng J.Q. 2013. Molecular cloning and expression analysis of hypoxia inducible factor $1 \alpha$ in tongue sole, Cynoglossus semilaevis (Actinopterygii: Pleuronectiformes: Cynoglossidae), subjected to acute hypoxia. Acta Ichthyol. Piscat. 43 (3): 201-209.
\end{abstract}

Background. Hypoxia-inducible factor- $1 \alpha(\mathrm{HIF}-1 \alpha)$, a subunit of the HIF-1 protein, plays a key role in the regulation of genes involved in hypoxia physiological response. Tongue sole, Cynoglossus semilaevis Günther, 1873, a marine teleost, had been proved to be a hypoxia-tolerant species. In this study, the HIF-1 $\alpha$ in tongue sole was cloned and its expression under acute hypoxia was examined to provide further basis for understanding the molecular response of tongue sole under hypoxia.

Materials and methods. The full length of HIF-1 $\alpha$ cDNA sequence was cloned from the liver of tongue sole by RT-PCR and RACE-PCR method. Then, the expression pattern of tongue sole HIF-1 $\alpha$ under acute hypoxic conditions were detected using quantitative real-time PCR method.

Results. The open reading frame of tongue sole HIF-1 $\alpha$ is $2208 \mathrm{bp}$, encoding 735 amino acids. The amino acid sequence of tongue sole HIF- $1 \alpha$ shared high identities $(52.7 \%-81.8 \%)$ with HIF-1 $\alpha$ from other vertebrates, and possessed six typical domains of the HIF-1 family (bHLH, PAS-A, PAS-B, PAC, N-TAD, and C-TAD). In adult fish, HIF-1 $\alpha$ mRNAs were highly expressed in the liver, moderately in the heart, spleen, kidney, stomach, blood and gills, and low in intestine. Under acute hypoxia stress, expression of HIF-1 $\alpha$ mRNAs were significantly upregulated in many tissues, including the liver, spleen, stomach, blood, heart and gills.

Conclusion. Tongue sole HIF-1 $\alpha$ possessed the similar sequence length, shared higher identities and clustered well with other known HIF-1 $\alpha$, thus revealing a high degree conservation of HIF-1 $\alpha$ during evolution. Tongue sole HIF-1 $\alpha$ began to be up-regulated from $5 \mathrm{~min}$ to $120 \mathrm{~min}$ after hypoxia, indicating that it might play a significant role at the early stage of hypoxia.

Keywords: Hypoxic stress, gene expression, quantitative real-time PCR

\section{INTRODUCTION}

Hypoxia-inducible factor-1 (HIF-1) is the master regulator of oxygen homeostasis by regulating more than 100 genes expression (Manolescu et al. 2009). HIF-1 is a heterodimer which is composed of two subunits, HIF- $1 \alpha$ and HIF-1 $\beta$. The two subunits belong to the helix-loop-helix (Bhlh)-Per-Arnt-Sim (PAS) family, which contain conserved structural domains, such as a bHLH domain and two PAS domains (Kewley et al. 2004). The HIF-1 $\beta$ subunit, also known as hydrocarbon nuclear translocator (ARNT), is constitutively expressed, and is not affected by oxygen tension (Wang et al. 1995). HIF-1 $\alpha$ is constitutively transcribed under normoxic conditions, but it is rapidly degraded via an ubiquitin-dependent pathway. However, during hypoxia this pathway is inhibited and HIF- $1 \alpha$ is translocated to the nucleus and dimerizes with HIF-1 $\beta$, causing HIF-1 to bind with hypoxia response elements (HREs) of target genes to activate their transcription (Maynard and Ohh 2004).

Currently, HIF-1 has been cloned and characterized in mammals (Gassmann et al. 2002), birds, amphibians, and some fish species (Cao et al. 2008, Kodama et al. 2012).

\footnotetext{
${ }^{*}$ Correspondence: Associate Prof. Zhitao Qi, 江省城市迎达道9号, 城工学院, 224051, 中国 (China), phone: +86-515-88298281, e-mail: qizhitao@ycit.edu.cn.
} 
However, there are little or limited studies with regard to fish HIF-1, especially when compared with high numbers of fish species worldwide. At the aquatic level, fish are the predominant species and are easily affected by oxygen availability (Wang et al. 2011). As a result, Fish have developed many strategies to adapt to low oxygen stresses during evolution, including decreasing metabolic rates, increasing anaerobic respiration, and increasing hematocrit and hemoglobin $\mathrm{O}_{2}$ affinities. It has been found that the majority of these strategies are regulated by HIF-1, suggesting the important role it plays in hypoxia adaptation. Recent studies showed that different fish HIF-1 $\alpha$ possessed distinctive expression patterns under normoxic or hypoxic conditions (Soitamo et al. 2001, Law et al. 2006, Rahman and Thomas 2007, Rojas et al. 2007, Shen et al. 2010). Thus, demonstrates that the regulation pathway of HIF-1 in different fish might be different.

Tongue sole, Cynoglossus semilaevis Günther, 1873, a marine teleost, is fast becoming an important aquatic species in China and other Asian countries (Shao et al. 2010) from the financial perspective. On this note therefore, our previous studies have found that this species was hypoxia-tolerant and could survive for several days under acute hypoxia stress $\left(\right.$ dissolved oxygen $=1.0 \mathrm{mg} \cdot \mathrm{L}^{-1}$ ). Some genes, e.g., transferrin and hemoglobin, were found to be up-regulated when tongue sole were subjected to hypoxia conditions (Wang et al. 2011, 2012). Hence, whether those genes were regulated by HIF-1 remains unclear. In the presently reported study, the HIF-1 $\alpha$ gene of tongue sole was identified and its expression patterns under normoxic and hypoxic conditions were examined. Therefore, the results provide the basis for further understanding the molecular response of tongue sole under hypoxia.

\section{MATERIALS AND METHODS}

Fish and acute hypoxia stress. Adult tongue sole, Cynoglossus semilaevis (mean length $24 \pm 1.01 \mathrm{~cm}$, mean weight $77.44 \pm 8.21 \mathrm{~g}$ ) were purchased from a fish farm at Ganyu county, Lianyungang city of Jiangsu Province and transferred to our laboratory by vehicle equipped with a water recirculation system. The fish were acclimated in 40-L tanks for 7 days before the hypoxia stress.

Then, total of 30 fish were randomly divided into six tanks connected to the same recirculation system. One tank (control group) was maintained under normoxic conditions: dissolved oxygen $(\mathrm{DO})=6.2 \mathrm{mg} \cdot \mathrm{L}^{-1}$. In the other tanks, gaseous nitrogen was bubbled through to induce acute hypoxic conditions $\left(\mathrm{DO}=1.0 \mathrm{mg} \cdot \mathrm{L}^{-1}\right)$. This DO concentration was chosen based on our previous results (Wang et al. 2011, 2012). Tissues from three fish were sampled at 5, 30, 60, 90 and $120 \mathrm{~min}$, and subsequently stored at $-80^{\circ} \mathrm{C}$ until required.

The Institutional Review Board of the Yancheng Institute of technology, China, approved this study as consistent with the country' s regulations on experiments on animals.

Total RNA extraction and first-strand cDNA synthesis. Total RNA of different tissues were extracted using TRIzol Reagent (Invitrogen, Carlsbad, CA, USA) accord- ing to the manufacturer's instructions. The quantity of RNA was determined by measuring the absorbance at 260 and $280 \mathrm{~nm}$. RNA integrity was determined by electrophoresis. After extraction, total RNA was reverse transcribed into cDNA in an $8-\mu \mathrm{L}$ reaction which comprised $1 \mu \mathrm{L}$ of CDS, $1 \mu \mathrm{L}$ of Smart II oligo (dT) primer, and 1-2 $\mu \mathrm{g}$ of total RNA. The reaction volume was made up to $8 \mu \mathrm{L}$ with DEPC-treated $\mathrm{H}_{2} \mathrm{O}$. The mix was heated at $72^{\circ} \mathrm{C}$ for $10 \mathrm{~min}$, chilled on ice for $2 \mathrm{~min}$, and then $4 \mu \mathrm{L}$ of $5 \times$ reverse transcription buffer, $2 \mu \mathrm{L}$ of $20 \mathrm{mM}$ DDT, $2 \mu \mathrm{L}$ of $10 \mathrm{mM}$ dNTPs, $1 \mu \mathrm{L}$ of $40 \mathrm{U} \cdot \mu \mathrm{L}^{-1}$ RNase inhibitor, $1 \mu \mathrm{L}$ of SuperScript ${ }^{\mathrm{TM}}$ Reverse Transcriptase (Invitrogen), and DEPC-treated $\mathrm{H}_{2} \mathrm{O}$ were added to a final volume of $20 \mu \mathrm{L}$. After incubation at $42^{\circ} \mathrm{C}$ for $1 \mathrm{~h}$, the reaction was terminated by heating at $72^{\circ} \mathrm{C}$ for $10 \mathrm{~min}$.

Cloning the tongue sole HIF-1a gene. Degenerate primers (HIF1DF1 and HIF1DR1) were designed using Primer 5.0 based on the conserved regions of known HIF$1 \alpha$ sequences from human (Homo sapiens) (GenBank Accession No. AF208487), mouse (Mus musculus) (NM_01043), rainbow trout (Oncorhynchus mykiss Walbaum, 1792) (AF304864) and grass carp (Ctenopharyngodon idella Valenciennes, 1844) (AY450269). The predicted product size was 1006 bp. Polymerase chain reaction (PCR) amplification was conducted in a total volume of $25 \mu \mathrm{L}$ which comprised $2 \mu \mathrm{L}$ of cDNA template, $2.5 \mu \mathrm{L}$ of $10 \times$ buffer, $2 \mu \mathrm{M} \mathrm{MgCl}_{2}$, $200 \mu \mathrm{M}$ dNTPs, $0.125 \mathrm{U}$ of ExTaq and $0.1 \mu \mathrm{M}$ primers. Thermal cycling involved an initial denaturation step at $94^{\circ} \mathrm{C}$ for $5 \mathrm{~min}$, followed by 30 cycles of $94^{\circ} \mathrm{C}$ for $30 \mathrm{~s}$, $60^{\circ} \mathrm{C}$ for $45 \mathrm{~s}$, and $72^{\circ} \mathrm{C}$ for $60 \mathrm{~s}$, and a final extension step of $72^{\circ} \mathrm{C}$ for $10 \mathrm{~min}$ after the 30 th cycle. Amplicons were extracted from agarose gels after electrophoresis and purified using a TaKaRa Agarose Gel Purification Kit (TaKaRa, Japan), then ligated into pMD18-T (TaKaRa) and sequenced on an automatic DNA sequencer (ABI Applied Biosystems Model 377).

Based on the obtained partial sequence, $3^{\prime}$ and $5^{\prime}$ rapid amplification of cDNA ends (RACE) were conducted using gene-specific primers and adaptor primers (UPM) to obtain the complete sequence of HIF-1 $\alpha$. For 3' RACE, the first-round PCR was performed using HIF1-3out and UPM as primers as well as subjected to an initial denaturation step of $94^{\circ} \mathrm{C}$ for $5 \mathrm{~min}$, then 9 cycles of $94^{\circ} \mathrm{C}$ for $30 \mathrm{~s}, 64^{\circ} \mathrm{C}$ for $30 \mathrm{~s}$ and $72^{\circ} \mathrm{C}$ for $90 \mathrm{~s}$, followed by 29 cycles of $94^{\circ} \mathrm{C}$ for $30 \mathrm{~s}, 62^{\circ} \mathrm{C}$ for $30 \mathrm{~s}$ and $72^{\circ} \mathrm{C}$ for $90 \mathrm{~s}$, with a final extension step of $72^{\circ} \mathrm{C}$ for $10 \mathrm{~min}$. Products of the first-round PCR were then diluted $(1: 10)$ and re-amplified by a second-round PCR with HIF13in/UPM as primers. For $5^{\prime}$ RACE, the first-round primers were HIF1-5out/UPM, and the second-round primers were HIF1-5in/UPM. The resulting products were analyzed as mentioned above. All primers used in our experiments were listed in Table 1.

Sequence analysis. The BLAST program was used to identify homologous sequences in the GenBank database. Deduced amino acids were predicted using software at the ExPASy molecular biology Server (http://www.expasy.org). 
Signal peptides were identified using the SignalP program (www.dtu.dk/services/SignalP). Multiple sequence alignments were conducted with CLUSTAL W 1.8 and amino acid identities were determined using MegAlign from the DNAStar software suite (Clewley and Arnold 1997). Phylogenetic trees were generated using the neighbor-joining (N-J) method with 1000 bootstraps by MEGA 5.1.2 (Kumar et al. 2008).

Quantitative real-time PCR (qPCR). Following total RNA extraction, samples were digested with RNase-free DNase I (TaKaRa) for $20 \mathrm{~min}$ at $37^{\circ} \mathrm{C}$ to remove genomic DNA. Approximately $2 \mu \mathrm{g}$ of RNA was transcribed into cDNA using a PrimeScript ${ }^{\circledR}$ RT reagent kit (TaKaRa) in a total volume of $10 \mu \mathrm{L}$ containing $2 \mu \mathrm{L}$ of total RNA, $2 \mu \mathrm{L}$ of $5 \times$ PrimeScript $^{\mathrm{TM}}$ Buffer $2 \mu \mathrm{L}, 0.5 \mu \mathrm{L}$ of PrimeScript ${ }^{\mathrm{TM}}$ RT Enzyme Mix I, $0.5 \mu \mathrm{L}$ of Oligo dT Primer $(50 \mu \mathrm{M}), 0.5 \mu \mathrm{L}$ of random hexamers $(100 \mu \mathrm{M})$, and $4.5 \mu \mathrm{L}$ of RNase-free double-distilled $\mathrm{H}_{2} \mathrm{O}$. Reactions were incubated at $30^{\circ} \mathrm{C}$ for $10 \mathrm{~min}, 42^{\circ} \mathrm{C}$ for $60 \mathrm{~min}$, and then $70^{\circ} \mathrm{C}$ for $15 \mathrm{~min}$. All cDNA samples were stored at $-20^{\circ} \mathrm{C}$ until required.

The partial sequence of tongue sole $\beta$-actin and HIF$1 \alpha$ were obtained and cloned into pMD18-T. The sequences were verified, and plasmid DNA were extracted using a QIAGEN plasmid mini kit (Qiagen, Valencia, CA, USA). Plasmid concentrations were determined using a spectrophotometer and measuring the optical density at $260 \mathrm{~nm}$. All qPCR experiments were performed on an ABI Real-time PCR system (Applied Biosystems 7500). Amplifications were carried out in a final volume of $20 \mu \mathrm{L}$ containing $1 \mu \mathrm{L}$ of cDNA template, $10 \mu \mathrm{L}$ of SYBR premix ExTaq, $0.4 \mu \mathrm{L}$ of $50 \times$ Rox reference dye, $1 \mu \mathrm{L}$ of each primer, and $7.1 \mu \mathrm{L}$ of double-distilled $\mathrm{H}_{2} \mathrm{O}$. Each sample was analyzed in triplicate using a two-step method, with an initial denaturation step at $95^{\circ} \mathrm{C}$ for $30 \mathrm{~s}$, followed by 40 cycles of $95^{\circ} \mathrm{C}$ for $5 \mathrm{~s}$ and $60^{\circ} \mathrm{C}$ for $31 \mathrm{~s}$. Specificity of the amplification reaction was determined using dissociation curves with the temperature ranging from $60-95^{\circ} \mathrm{C}$. Gene expression levels in normal tissue were measured relative to the expression of the $\beta$-actin gene, and fold-changes after hypoxic exposure were calculated by a previously described method (Qi et al. 2011). Results were first analyzed using the ABI Prism 7500 SDS program with final statistical analysis conducted with Microsoft Excel. The significance of the data was evaluated using Student's $t$-test, with a $P$-value less than 0.05 considered statistically significant. All primers used in the qPCR assays were listed in Table 1.

\section{RESULTS}

Cloning and characterization of tongue sole HIF-1 $\alpha$. Using degenerate primers, a partial sequence of $1002 \mathrm{bp}$ was cloned from liver cDNA. This sequence shared high identities with grass carp HIF-1 $\alpha$, thereby confirming that the cloned sequence was a partial sequence of tongue sole HIF-1 $\alpha$. Full-length of tongue sole HIF- $1 \alpha$ cDNA was obtained using 5' and 3' RACE (GenBank Accession No. HQ909440) which was found to be $3460 \mathrm{bp}$. This sequence contained a $5^{\prime}$ untranslated region (5'-UTR) of $243 \mathrm{bp}$, an open reading frame (ORF) of $2208 \mathrm{bp}$ encoding 735 amino acid (aa) residues, and a 3'-UTR of $1009 \mathrm{bp}$ which includes five mRNA instability elements and a polyA signal sequence.

Sequence alignment showed that tongue sole HIF-1 $\alpha$ shared high identities with HIF-1 $\alpha$ in human $(52.7 \%)$, frog (Xenopus tropicalis) (54.2\%), zebrafish (Danio rerio Hamilton, 1822) (63.5\%), Japanese flounder (Paralichthys olivaceus) (80.1\%) and seabass (Lateolabrax japomcus Linnaeus, 1758) (81.8\%). Tongue sole HIF-1 $\alpha$ also contained six conserved domains found in members of the HIF- $\alpha$ family: bHLH; PAS-A; PAS-B; C-terminal of PAS (PAC); N-terminal transactivation domain (N-TAD); and C-TAD. Meanwhile, some important motifs or amino acids needed for HIF-1 $\alpha$ functions were also observed in tongue sole HIF-1 $\alpha$ (Fig. 1). The N-terminal nuclear localization signal (N-NLS) at residues 17-64 and C-NLS (residues 637-642) play an important role in regulating nucleocytoplasmic trafficking

Sequences of oligonucleotide primers used in the presently reported study

\begin{tabular}{lll}
\hline Primer & Sequence $\left(5^{\prime}\right.$ to 3') $^{\prime}$ & Purpose \\
\hline HIF1DF1 & TGA GCT CGG AG(C) CGG (C)AG A(G)A AG & $\begin{array}{l}\text { Partial sequence } \\
\text { cloning }\end{array}$ \\
\hline HIF1DR1 & A(G)T G(A)C CAC TGA GC(A) ACA (G)T(A) AGT T & \\
HIF1-5in & GGT GAG TCT CAT GAT GGA AGC C & \\
HIF1-3out & TGG GCC AGC TCG TAG AAA ACC T & \\
HIF1-3in & CAG AGA TTC AGT TGC TGA ATG & RACE PCR \\
UPM & & \\
Long & CTA ATA CGA CTC ACT ATA GGG CAA GCA GTG GTA TCA ACG CAG AGT & \\
Short & CTA ATA CGA CTC ACT ATA GGG C & \\
\hline QHIF1-F1 & TGA GCT CGG AGC GCA GAA AG & qPCR \\
QHIF1-R1 & CTG GGT TGA GCA GCT TCC TG & \\
Qactin-F1 & CAG CCA TAC TGT GCC CAT CT & \\
Qactin-R1 & TCC TTG ATG TCA CGC ACG AT &
\end{tabular}



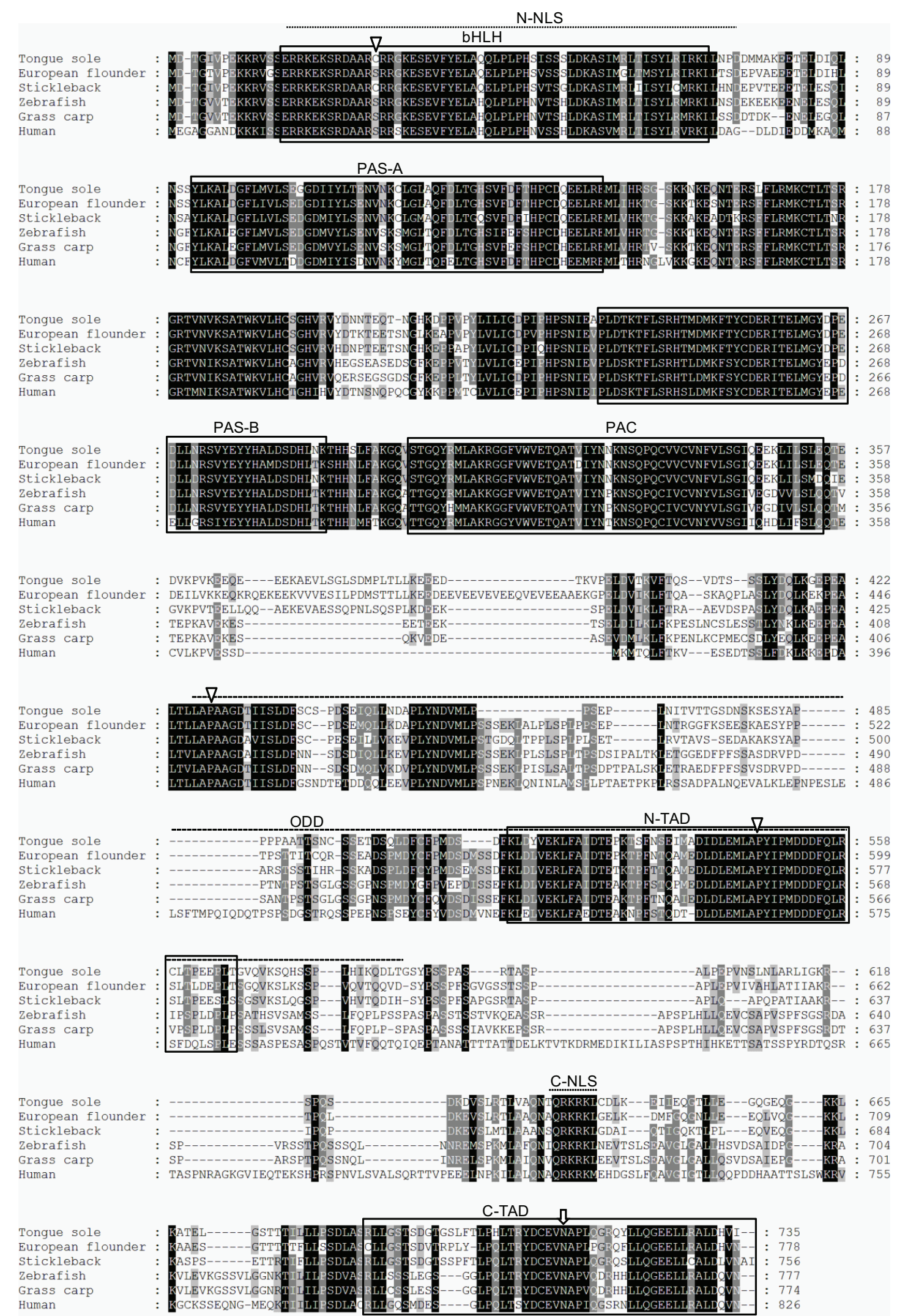

Fig. 1. Alignment of HIF-1 $\alpha$ amino acid sequences from different vertebrate species. Alignment was performed using ClustalW version 2.0 and GeneDoc; Gaps are marked by dashes; The HIF-1 $\alpha$ functional regions (bHLH, PAS-A, PAS-B, PAC, N-TAD, and C-TAD) are boxed; Domains are labelled above the alignments; The two conserved proline (Pro) residues are indicated with the inverted solid triangles; Residue substitutions are marked with an inverted triangle; The white inverted triangle indicates an asparagine residue; Sequences used for this analysis were obtained from NCBI database, and the accession numbers were listed in the caption of Fig. 3. 
of the HIF-1 $\alpha$ protein (Luo and Shibuya 2001). Pro-402 mediates the degradation of HIF- $1 \alpha$ under normoxic conditions (Masson et al. 2001), while Pro-564, Tyr-565 and Ile-566 are conserved in the pVHL recognition sequence (PYIXXDDDFXL) within the N-TAD domain, and play an important role in controlling ubiquitin/proteasome degradation of HIF-1 $\alpha$ under normoxic conditions (Pereira et al. 2003). Leu-574 will likely modulates the proteolysis of HIF- $1 \alpha$ by determining the hydroxylation of Pro-564 (Kageyama et al. 2004). Similar to C-TAD in human HIF-1 $\alpha$, the C-TAD of tongue sole HIF-1 $\alpha$ is leucine-rich and contains Asn-803, Leu-795, Cys-800, Leu-818 and Leu-822, which are required for the interaction of $\mathrm{HIF}-1 \alpha$ with $\mathrm{CBP} / \mathrm{p} 300$ transactivators and play an essential role in activation of the HIF-1 transcriptional pathway (Ruas et al. 2002). Comparison of the different domains in human, zebrafish and tongue sole HIF-1 $\alpha$ showed that the domains shared high identities among each other. The domains in tongue sole HIF-1 $\alpha$ shared higher homologies with those in zebrafish HIF-1 $\alpha$ than in human HIF-1 $\alpha$ (Fig. 2).

Using the grass carp HIF-4 $\alpha$ as an outgroup, a phylogenetic tree was constructed using MEGA 5.1.2 software. The tree was separated into two main clades, one containing HIF-1 $\alpha$ from mammals, amphibians, reptile and birds, and the second one contained fish HIF-1 $\alpha$. The clade that contained fish HIF-1 $\alpha$ was divided into two clusters. One cluster consisted of HIF-1 $\alpha$ from zebrafish, grass carp and common carp (Cyprinus carpio Linnaeus, 1758.), while the second one was further divided into two closely-related sub-clusters with high bootstrap value (99\%). The tongue sole HIF-1 $\alpha$ clustered closely with European flounder (Platichthys flesus Linnaeus, 1758) HIF-1 $\alpha$ (bootstrap value: 86 ) in the sub-clusters containing all HIF-1 $\alpha$ of marine teleost (Fig. 3).

Expression of tongue sole HIF-1a under normoxic conditions. Under normoxic conditions, tongue sole HIF$1 \alpha$ mRNA was highly expressed in the liver, moderately expressed in the heart, spleen, kidney, stomach, blood and gills. Low levels of expression were observed for intestinal samples (Fig. 4).

Changes of tongue sole HIF-1 $\alpha$ transcripts under acute hypoxic conditions. Compared with the control group, the expression of tongue sole HIF- $1 \alpha$ mRNA was significantly up-regulated after $30 \mathrm{~min}$ of hypoxic stress $(P<0.05)$. Hence, as the time subjected to hypoxic stress was increased, so did the mRNA levels in different tissues. Liver HIF-1 $\alpha$ levels increased 28.99- and 28.78-fold after 90 and 120 min, respectively; while HIF-1 $\alpha$ expression levels in gills increased 17.08- and 19.18-fold after 90 and $120 \mathrm{~min}$, respectively, of hypoxic stress (Fig. 5).

\section{DISCUSSION}

In the presently reported study the characterization and expression of HIF-1 $\alpha$ have been studied from a marine teleost - tongue sole, Cynoglossus semilaevis. The predicted length of amino acids sequence of tongue sole HIF-1 $\alpha$ was 735 aa which was very similar to HIF-1 $\alpha$ from other vertebrates. The HIF-1 $\alpha$ of tongue sole shared higher identities of amino acids sequence with fish HIF$1 \alpha(63.5 \%-81.8 \%)$ than human $(52.7 \%)$ and frog $(54.2 \%)$ HIF-1 $\alpha$. Similar to other vertebrates HIF-1 $\alpha$, tongue sole HIF-1 $\alpha$ also contained six highly conserved domains of HIF- $\alpha$ family members (bHLH, PAS-A, PAS-B, PAC, N-TAD, and C-TAD) and some motifs or amino acids involved in modulating the degradation of HIF-1 $\alpha$ under normoxic conditions (e.g., Pro-402 and Leu574) (Masson et al. 2001, Kageyama et al. 2004). Those results suggested a high degree of conservation for HIF-1 $\alpha$ during evolution. Interestingly, there were some substitutions of amino acids observed in tongue sole and other vertebrates HIF- $\alpha$. It had been speculated that those substitutions might affect protein conformation and could possibly function to counteract effects of low temperature on HIF-1 $\alpha$ conformation in other vertebrate (Morin and Storey 2005, Rytkönen et al. 2007, Shen et al. 2010).

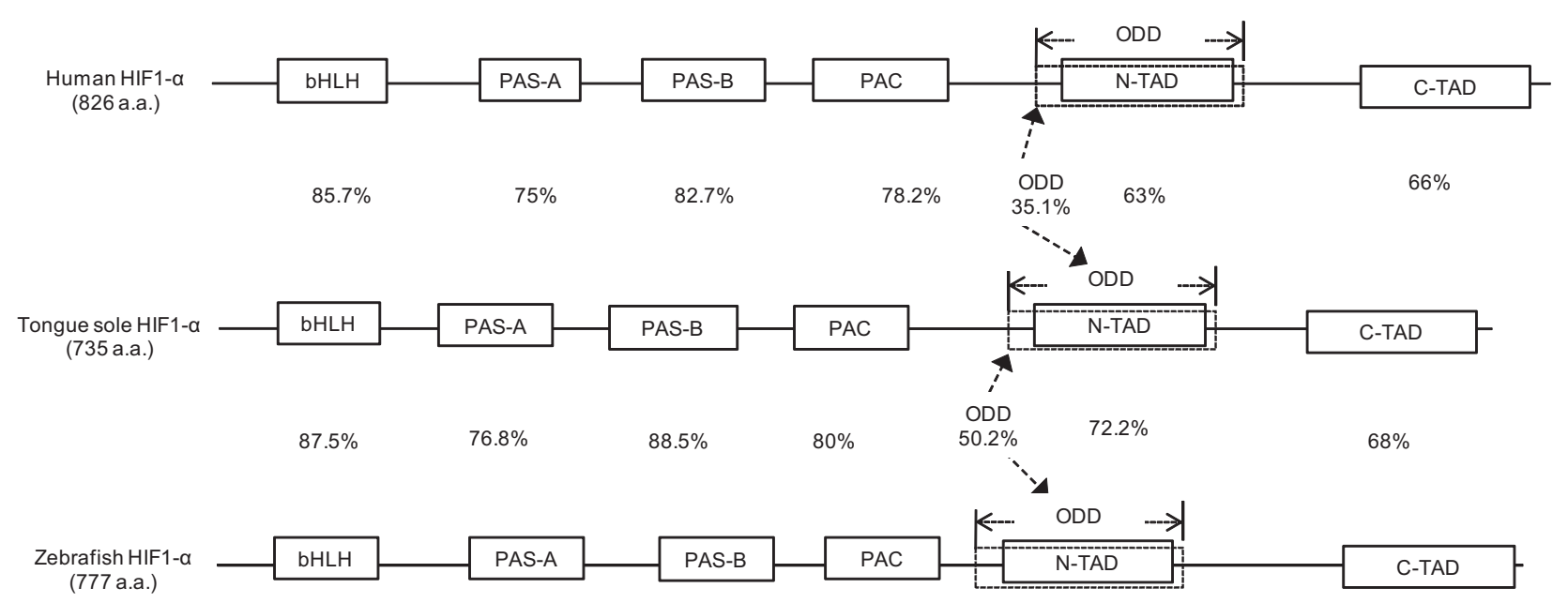

Fig. 2. Comparison of amino acid sequence identities among functional domains of HIF-1 $\alpha$. The conserved domains include bHLH, PAS-A, PAS-B, PAC, N-TAD, and C-TAD; These are marked with boxes using a solid line; ODD is indicated by a box with a dotted line; Amino acid identities are presented as percentages. 
Our phylogenetic tree analysis showed that the HIF-1 $\alpha$ from the evolutionary closely-related species were well clustered together - for example — grass carp and common carp. Thus, it was not surprising that HIF-1 $\alpha$ of two pleuronectiform fish: tongue sole and European flounder were clustered in the same small branch with high bootstrap value (86\%). Rytkönen et al (2007) found out that European flounder may be considered a hypoxia-tolerant fish. Hence, the combination of our previous studies and current analysis confirmed that the tongue sole was exactly a hypoxia-tolerant species.

Under normoxic conditions, tongue sole HIF-1 $\alpha$ transcription constitute was expressed in all the examined tis- sues, highly in the liver, moderately in heart, spleen, kidney, stomach, blood and gills and low in intestine. This expression pattern was consistent with the studies in European seabass, Wuchang bream ( Megalobrama amblycephala Yih, 1955) and Chinese sucker (Myxocyprinus asiaticus) (Terova et al. 2008, Shen et al. 2010, Chen et al. 2012). Unlike HIF-1 $\alpha$ in these three teleost, HIF-1 $\alpha$ of grass carp was highly expressed in the eyes and kidneys (Law et al. 2006). HIF-1 $\alpha$ of zebrafish was expressed mainly in the gill, ovary and brain (Rojas et al. 2007), and HIF-1 $\alpha$ of Atlantic croaker, Micropogonias undulatus (Linnaeus, 1766), was abundantly expressed in the brain

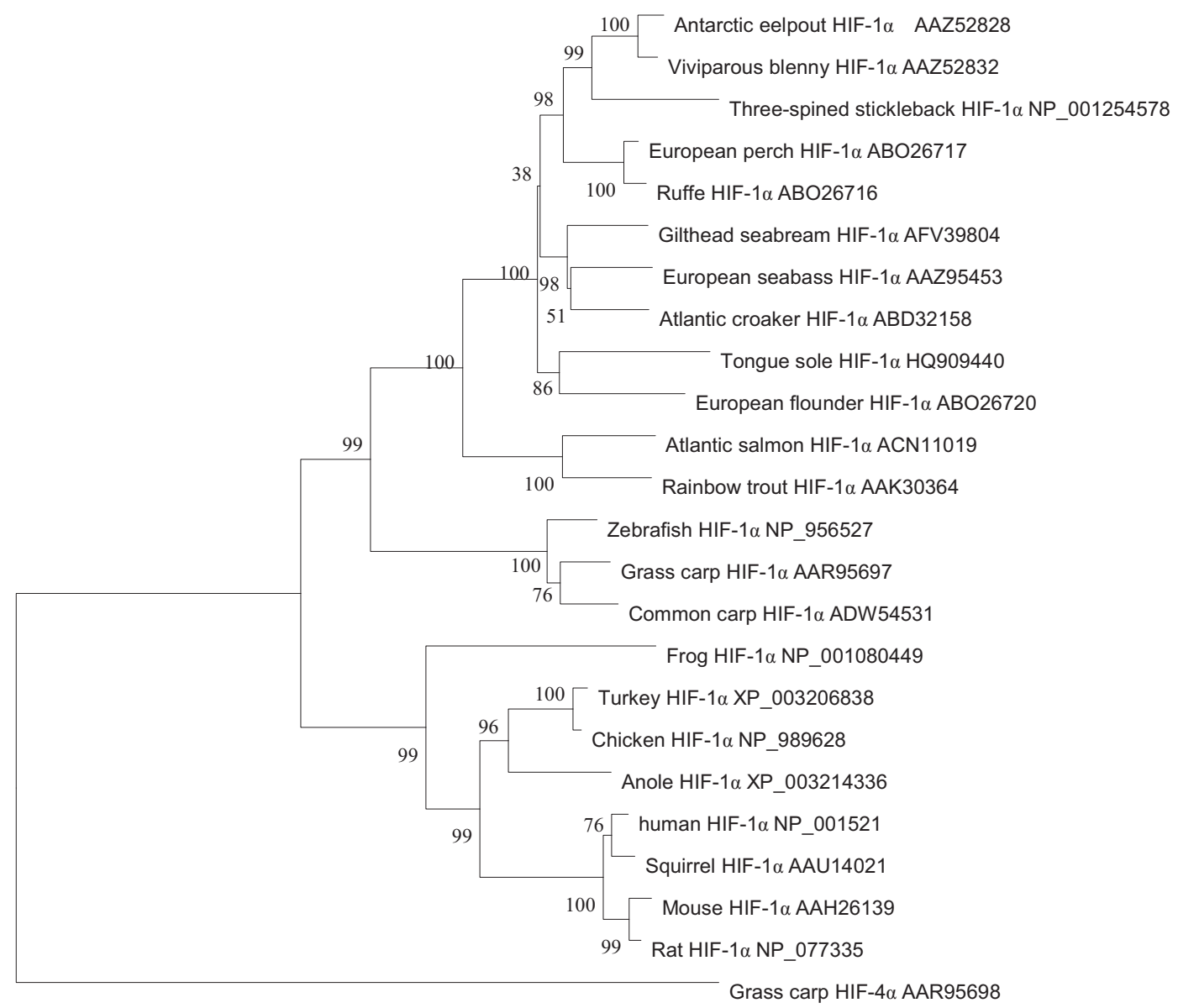

0.1

Fig. 3. Phylogenetic tree of HIF-1 $\alpha$ of selected vertebrate species showing the position of HIF-1 $\alpha$ of tongue sole, Cynoglossus semilaevis.Bootstrap values were generated by testing the tree 10000 times using MEGA 5.1.2. The GeneBank accecssion numbers of HIF-1 $\alpha$ sequence used for this analysis were: human Homo sapiens, NP_001521; squirrel Ictidomys tridecemlineatus, AAU14021; mouse Mus musculus, AAH26139; rat Rattus norvegicus NP_077335; trukey Meleagris gallopavo, XP_003206838; chicken Gallus gallus, NP_989628; anole Anolis carolinensis, XP_003214336; frog Xneopus tropicalis, NP_001080449; common carp Cyprinus carpio, ADW54531; grass carp Ctenopharyngodon idella, AAR95697; zebrafish Danio rerio, NP_956527; rainbow trout Oncorhynchus mykiss, AAK30364; atlantic salmon Salmo salar, ACN11019; eurpean flounder Platichthys flesus, ABO26720; tongue sole Cynoglossus semilaevis HQ909440; atlantic croaker Micropogonias undulatus, ABD32158; european seabass Dicentrarchus labrax, AAZ95453; gilthead seabream Sparus aurata AFV39804; ruffe Gymnocephalus cernuus ABO26716; european perch Perca fluviatilis, ABO26717; three-spined stickleback Gasterosteus aculeatus, NP_001254578; viviparous blenny Zoarces viviparus, AAZ52832; Antarctic eelpout Pachycara brachycephalum, AAZ52828; and HIF-4 $\alpha$ from grass carp was AAR95698. The GeneBank accecssion numbers for the sequeses used for this analysis were also listed next to the vertebrate names. 
and gonads (Rahman and Thomas 2007). The distinctive expression of HIF-1 $\alpha$ suggested that this gene might possess different physiological functions in different fish species (Chen et al. 2012).

Under hypoxic conditions, HIF-1 $\alpha$ transcription levels also exerted distinctive patterns. In rainbow trout and Wuchang bream mRNA levels of HIF-1 $\alpha$ remained stable (Soitamo et al. 2001, Shen et al. 2010). However, in grass carp, the mRNA levels of HIF-1 $\alpha$ were increased significantly in the gills and kidneys after $4 \mathrm{~h}$ of hypoxia, yet decreased in the brain, heart and liver, and remained unchanged in the eyes (Law et al. 2006). Studies from Atlantic croaker and Chinese sucker also found an increasing pattern for HIF-1 $\alpha$ mRNA when the fish were subjected to short-term or long-term hypoxic stress (Rahman and Thomas 2007, Chen et al. 2012. In the presently reported study, following the short-term hypoxic stress the mRNA expression levels of tongue sole increased significantly in some examined tissues, suggesting that tongue sole HIF-1 $\alpha$ might exert its function at the early stage of hypoxia. Studies in mammals showed that members of the HIF family (HIF-1 $\alpha,-2 \alpha$ and $-3 \alpha$ ) might play different roles at different stage of hypoxia (Heidbreder et al. 2003, Ratcliffe, 2007). Whether members of fish HIF family also had distinctive function in different stage of hypoxia needs to be further studied. The significantly increase in the HIF- $1 \alpha$ level also explained why tongue sole was a hypoxia-tolerant species which could survive for a longer period than other fish species under acute hypoxic conditions (Wang et al. 2011, 2012).

In conclusion, we have identified the HIF-1 $\alpha$ isoform in a hypoxia-tolerant marine fish, tongue sole, and analyzed its expression pattern under normoxic and hypoxic stress. Sequence analysis showed that tongue sole HIF-1 $\alpha$ possessed similar sequence length, shared higher identities and cluster well with other known HIF-1 $\alpha$, revealing a high degree conservation of HIF-1 $\alpha$ during evolution. Tongue sole HIF-1 $\alpha$ begins up-regulated from 5 min to 120 min after hypoxia, indicating that it might play significant roles at the early stage of hypoxia.

\section{ACKNOWLEDGEMENTS}

This work was supported by the grants from the National Natural Science Foundations of China (no. 31302221) and Jiangsu Province (BK2011418) and the Post-doctoral Science Foundation of China (2012M521095 and 2013T60547).

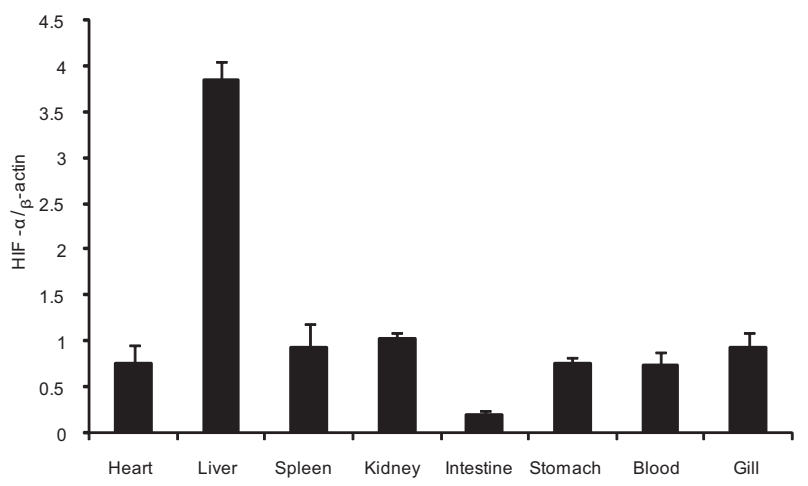

Fig. 4. Tissue distribution of HIF- $1 \alpha$ in healthy tongue sole, Cynoglossus semilaevis; Expression of HIF-1 $\alpha$ was measured by normalizing to the expression of $\beta$-actin using qPCR method; Each sample was analyzed in triplicate

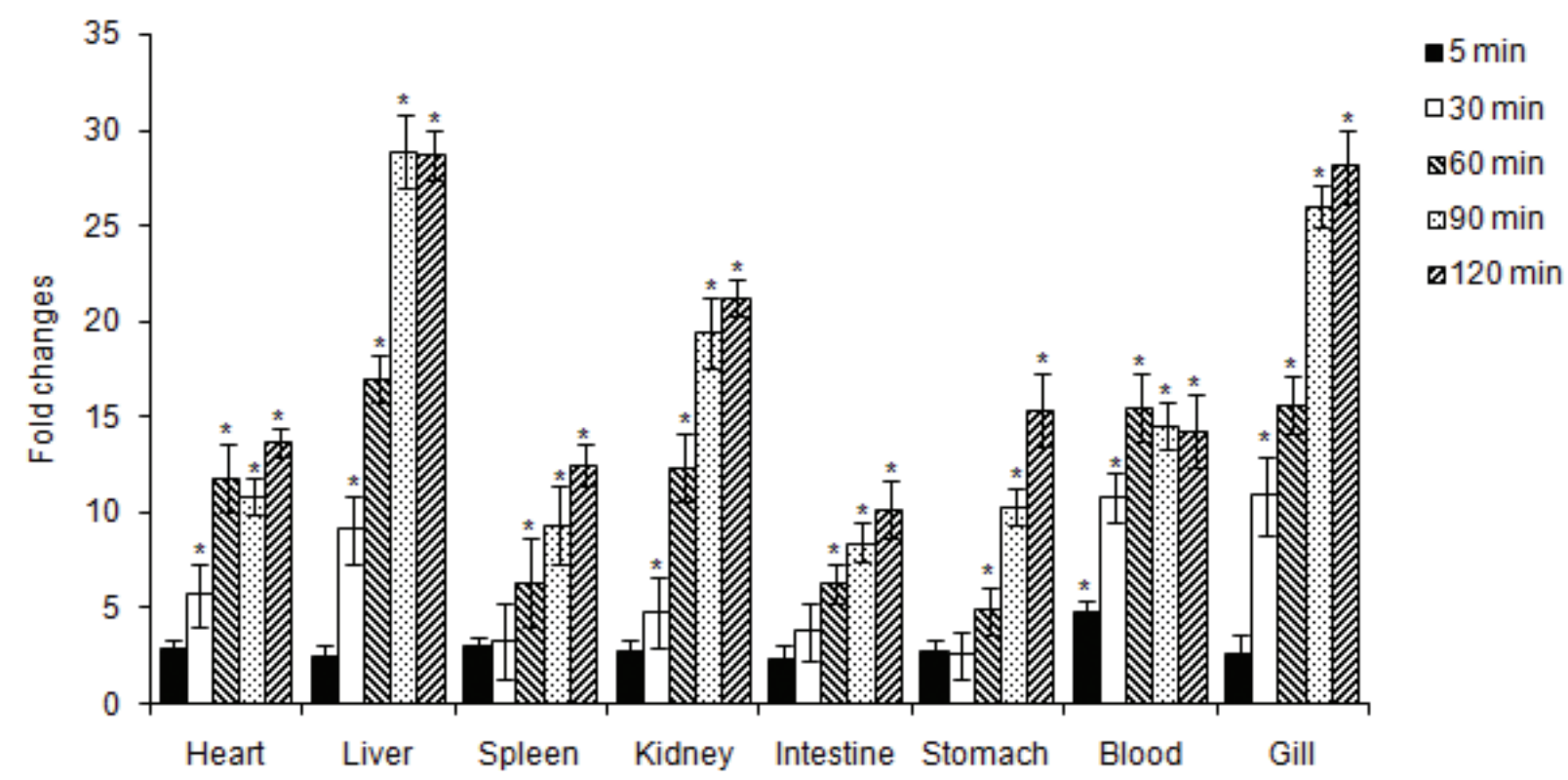

Fig. 5. HIF-1 $\alpha$ expression patterns in different tissues of tongue sole, Cynoglossus semilaevis, subjected to acute hypoxia for 5-120 min; The fold-change in HIF-1 $\alpha$ expression was calculated using the formula: fold changes = fold-change in target expression (experimental group/control group)/fold-change in reference gene expression (experimental group/control group); Samples were analyzed in triplicate; ${ }^{*} P<0.05$ 


\section{REFERENCES}

Cao Y.B., Chen X.Q., Wang S., Wang Y. X., Du J.Z. 2008. Evolution and regulation of the downstream gene of hypoxiainducible factor- $1 \alpha$ in naked carp (Gymnocypris przewalskii) from lake Qinghai, China. Journal of Molecular Evolution 67 (5): 570-580. DOI: 10.1007/s00239-008-9175-4

Chen N., Chen L.P., Zhang J., Chen C., Wei X.L., Gul Y., Wang W.M., Wang H.L. 2011. Molecular characterization and expression analysis of three hypoxia-inducible factor alpha subunits, HIF- $1 \alpha / 2 \alpha / 3 \alpha$ of the hypoxia-sensitive freshwater species, Chinese sucker. Gene 498 (1): 81-90. DOI: 10.1016/j.gene.2011.12.058

Clewley J.P., Arnold C. 1997. Megalign: The multiple alignment module of LASERGENE. Pp. 119-129. In: Swindell S.R. (ed.) Sequence Data Analysis Guidebook. Series: Methods in Molecular Biology. Vol. 70. Springer, New York, USA. DOI: $10.1385 / 0-89603-358-9: 119$

Gassmann M., Chilov D., Wenger R.H. 2002. Regulation of the hypoxia-inducible factor- $1 \alpha$. ARNT is not necessary for hypoxic induction of HIF-1 $\alpha$ in the nucleus. Pp. 87-99. In: Lahiri S., Prabhakar N.R., Forster R.E.II (eds.) Oxygen sensing: Molecule to man. Series: Advances in Experimental Medicine and Biology. Vol. 475. Springer US. DOI: 10.1007/0-306-46825-5_9

Heidbreder M., Fröhlich F., Jöhren O., Dendorfer A., Oadri F., Dominiak P. 2003. Hypoxia rapidly activates HIF-3 $\alpha$ mRNA expression. The FASEB Journal 17 (11): 1541-1543. DOI: 10.1096/fj.02-0963fje

Kageyama Y., Koshiji M., To K.K.W., Tian Y. M., Ratcliffe P.J., Huang L.E. 2004. Leu-574 of human HIF-1 $\alpha$ is a molecular determinant of prolyl hydroxylation. The FASEB Journal 18 (9): 1028-1030. DOI: 10.1096/fj.03-1233fje

Kewley R.J., Whitelaw M.L., Chapman-Smith A. 2004. The mammalian basic helix-loop-helix/PAS family of transcriptional regulators. International Journal of Biochemistry and Cell Biology 36 (2): 189-204. DOI: 10.1016/S13572725(03)00211-5

Kodama K., Rahman M.S., Horiguchi T., Thomas P. 2012. Upregulation of hypoxia-inducible factor (HIF)-1 $\alpha$ and HIF$2 \alpha$ mRNA levels in dragonet Callionymus valenciennei exposed to environmental hypoxia in Tokyo Bay. Marine Pollution Bulletin 64 (7): 1339-1347. DOI: 10.1016/j.marpolbul.2012.05.002

Kumar S., Dudley J., Nei M., Tamura K. 2008. MEGA: a biologist-centric software for evolutionary analysis of DNA and protein sequences. Briefings in Bioinformatics 9 (4): 299-306. DOI: 10.1093/bib/bbn017

Law S.H.W., Wu R.S.S., Ng P.K.S., Yu R.M., Kong R.Y. 2006. Cloning and expression analysis of two distinct HIFalpha isoforms-gcHIF-1alpha and gcHIF-4alpha-from the hypoxia-tolerant grass carp, Ctenopharyngodon idellus. BMC Molecular Biology 7 [paper 15]: 13 pages]. DOI: 10.1186/1471-2199-7-15

Luo J.C., Shibuya M. 2001. A variant of nuclear localization signal of bipartite-type is required for the nuclear translocation of hypoxia inducible factors (1,2 and 3). Oncogene 20 (12): 1435-1444.

Manolescu B., Oprea E., Busu C., Cercasov C. 2009. Natural compounds and the hypoxia-inducible factor (HIF) sig- nalling pathway. Biochimie 91 (11-12): 1347-1358. DOI: 10.1016/j.biochi.2009.08.005

Masson N., Willam C., Maxwell P.H., Pugh C.W., Ratcliffe P.J. 2001. Independent function of two destruction domains in hypoxia-inducible factor- $\alpha$ chains activated by prolyl hydroxylation. The EMBO Journal 20 (18): 5197-5206. DOI: $10.1093 / \mathrm{emboj} / 20.18 .5197$

Maynard M.A., Ohh M. 2004. von Hippel-Lindau tumor suppressor protein and hypoxia-inducible factor in kidney cancer. American Journal of Nephrology 24 (1): 1-13. DOI: 10.1159/000075346

Morin P.J., Storey K.B. 2005. Cloning and expression of hypoxia-inducible factor 1 alpha from the hibernating ground squirrel, Sermophilus tridecemlineatus. Biochimica et Biophysica Acta 1729(1): 32-40. DOI: 10.1016/ j.bbaexp.2005.02.009

Pereira T., Zheng X., Ruas J.L., Tanimoto K., Poellinger L. 2003. Identification of residues critical for regulation of protein stability and the transactivation function of the hypoxiainducible factor- $1 \alpha$ by the von Hippel-Lindau tumor suppressor gene product. Journal of Biological Chemistry 278 (9): 6816-6823. DOI: 10.1074/jbc.M209297200

Qi Z.T., Zhang Q.H., Wang Z.S., Wang A.M., Huang B., Chang M.X., Nie P. 2011. Cloning and expression analysis of a long type peptidoglycan recognition protein (PGRP-L) from Xenopus tropicalis. Zoological Research 32 (4): 371-378. DOI: 10.3724/SP.J.1141.2011.04371

Rahman M.S., Thomas P. 2007. Molecular cloning, characterization and expression of two hypoxia-inducible factor alpha subunits, HIF- $1 \alpha$ and HIF- $2 \alpha$, in a hypoxia-tolerant marine teleost, Atlantic croaker (Micropogonias undulatus). Gene 396 (2): 273-282. DOI: 10.1016/j.gene.2007.03.009

Ratcliffe P.J. 2007. HIF-1 and HIF-2: working alone or together in hypoxia? Journal of Clinical Investigation 117 (4): 862-865. DOI: $10.1172 / \mathrm{JCI} 31750$

Rojas D.A., Perez-Munizaga D.A., Centanin L., Antonelli M., Wappner P., Allende M.L., Reyes A.E. 2007. Cloning of hif- $1 \alpha$ and hif- $2 \alpha$ and mRNA expression pattern during development in zebrafish. Gene Expression Patterns 7 (3): 339-345. DOI: 10.1016/j.modgep.2006.08.002

Ruas J.L., Poellinger L., Pereira T. 2002. Functional analysis of hypoxia-inducible factor- $1 \alpha$-mediated transactivation. Identification of amino acid residues critical for transcriptional activation and/or interaction with CREB-binding protein. Journal of Biological Chemistry 277 (41): 38723-38730. DOI: 10.1074/jbc.M205051200

Rytkönen K.T., Vuori K.A.M., Primmer C.R., Nikinmaa M. 2007. Comparison of hypoxia-inducible factor-1 alpha in hypoxia-sensitive and hypoxia-tolerant fish species. Comparative Biochemistry and Physiology Part D: Genomics and Proteomics 2 (2): 177-186. DOI: 10.1016/j.cbd.2007.03.001

Shao C.W., Chen S.L., Scheuring C.F., Xu J.Y., Sha Z.X., Dong X.L., Zhang H.B. 2010. Construction of two BAC libraries from half-smooth tongue sole Cynoglossus semilaevis and identification of clones containing candidate sexdetermination genes. Marine Biotechnology 12 (5): 558-568. DOI: 10.1007/s10126-009-9242-x 
Shen R.J., Jiang X.Y., Pu J.W., Zou S.M. 2010. HIF-1 $\alpha$ and $2 \alpha$ genes in a hypoxia-sensitive teleost species Megalobrama amblycephala: cDNA cloning, expression and different responses to hypoxia. Comparative Biochemistry and Physiology Part B: Biochemistry and Molecular Biology 157 (3): 273-280. DOI: 10.1016/j.cbpb.2010.06.013

Soitamo A.J., Råbergh C.M.I., Gassmann M., Sistonen L., Nikinmaa M. 2001. Characterization of a hypoxiainducible factor $(\mathrm{HIF}-1 \alpha)$ from rainbow trout. Accumulation of protein occurs at normal venous oxygen tension. Journal of Biological Chemistry 276 (23): 19699-19705. DOI: 10.1074/jbc.M009057200

Terova G., Rimoldi S., Corà S., Bernardini G., Gornati R., Saroglia M. 2008. Acute and chronic hypoxia affects HIF$1 \alpha$ mRNA levels in sea bass (Dicentrarchus labrax). Aquaculture 279 (1-4): 150-159. DOI: 10.1016/ j.aquaculture.2008.03.041

Wang G.L., Jiang B.H., Rue E.A., Semenza G.L. 1995. Hypoxia inducible factor 1 is a basic-helix-loop-helix-PAS heterodimer regulated by cellular $\mathrm{O}_{2}$ tension. Proceedings of the National Academy of Science of the United States of America 92 (12): 5510-5514.

Wang Z.S., Qi Z.T., Qiu M., Zhao W.H., Wang A.M., Huang J.T., Guo X.J. 2011. Changes of globins expression in tongue sole, Cynoglossus semilaevis (Actinopterygii: Pleuronectiformes: Cynoglossidae) in response to shortterm hypoxia. Acta Ichthyological et Piscatoria 41 (3): 179-184. DOI: 10.3750/AIP2011.41.3.05

Wang Z.S., Qi Z.T., Zhang Q.H., Qiu M., Huang J.T., Zhao W.H., Guo X.J. 2012. The cDNA sequence of the transferrin gene in tongue sole (Cynoglossus semilaevis) and its transcriptional changes under acute hypoxic stress. Italian Journal of Animal Science 11 (4): 419-425. DOI: 10.4081/ ijas.2012.e74

Received: 14 March 2013

Accepted: 29 June 2013

Published electronically: 30 September 2013 